\title{
Supply chain practices and organizational performance: Evidence from Jordanian medical devices firms
}

\author{
Faisal Al-Madia ${ }^{a}$ Tasneem Alfalah ${ }^{\mathrm{b}}$, Ata Al Shraah ${ }^{\mathrm{a}}$ and Ayman Abu-Rumman ${ }^{\mathrm{c}^{*}}$
}

${ }^{a}$ Business Administration Department, Faculty of Economics \& Administrative Sciences, The Hashemite University, Zarqa, Jordan

${ }^{b}$ Graduate School of Business Administration, German Jordanian University, Amman, Jordan

${ }^{c}$ Business School, Al-Ahliyya Amman University, Amman, Jordan

\section{H R O N I C L E}

Article history:

Received March 12, 2021

Received in revised format May 8, 2021

Accepted August 122021

Available online

August 122021

Keywords:

Supply chain practices

Organizational performance

Medical Devices Firms

Jordan

\section{A B S T R A C T}

The study aimed at determining the extent to which Jordanian medical devices adopted the supply chain practices and to investigate the impact of those practices on organizational performance of the Jordanian medical devices' firms. A cross-sectional approach was used to meet the purpose. A robust questionnaire was designed and used to collect primary data from the study sample. 200 questionnaires were completed and returned by the participants. SPSS version 21 and SEM were employed, with the use of (AMOS:21) to analyze and explain the collected data and to validate the research framework. The results demonstrated that medical devices firms in Jordan have adopted the supply chain practices and revealed a significant impact of those practices on the performance of the medical devices in Jordanian context.

(C) 2021 Growing Science Ltd. All rights reserved.

\section{Introduction}

Many scholars have examined the impact of supply chain practices (SCPs) on organizational performance (OP) using different variables, whether for SCPs or OP. In general, previous studies have agreed that SCPs have a positive impact on operational performance (Sharma \& Modgil 2019, Phan et al. 2019, Al-Madi, 2017, Bozarth et al., 2009; Cai et al., 2009; Lawson et al., 2009; Lenny et al., 2007; Miguel and Brito, 2011). Some studies that have focused specifically on financial performance have again found a positive relationship between SCPs and financial success (Salhieh, 2011; Karimi and Rafiee, 2014; Wagner et al., 2012). Long-term relationships between organization and suppliers (local or global), can help to reduce the production process costs through the development of trust and reputation and achieve significant ongoing benefits (Xiao et al., 2019; AlAli \& Abu-Rumman, 2019). To ensure customer satisfaction, leading organizations try to designate suitable suppliers to meet the demand of all customers (Abu-Rumman, et al., 2021; Choy et al., 2002). The level of information sharing (quantity aspect) could be defined as the extent to which information is communicated to any of the supply chain members (Tan, 2002). By taking available information and sharing it with other parties within the supply chain, organizations can achieve a competitive advantage (Hsu et al., 2009). The level of information quality is considered with other aspects of information quality such as timeliness, adequacy, accuracy, and reliability, which is important as many failed projects around the world were caused because of inappropriate information and communication. Scholars like: Beamon, (1998) and Johnson and Davis, (1998), defined postponement as the process of moving forward one or more activities such as making, sourcing, and delivering to a later stage in the supply chain. Organizational performance (OP) refers to how well an organization achieves its market and none- market oriented goals (Yasmin et al., 1999; Al Shraah et al., 2021). From the point view of Garcia (2005) and Tharenou et al. (2007), the potential indicators of OP include profits, return on investment, market share, return on assets, and return on equity. After an extensive review of the most recent literature, five distinctive dimensions have been selected to measure SCPs including strategic supplier partnership; customer relationship management; level of information sharing; quality of information sharing; and postponement (Li et al., 2006).

* Corresponding author

E-mail address: a.aburumman@ammanu.edu.jo (A. Abu-Rumman)

(C) 2021 Growing Science Ltd. All rights reserved.

doi: $10.5267 /$ j.uscm.2021.8.006 


\section{Theoretical framework}

\subsection{Supply Chain Management}

Supply chain management is considered as a growing multidisciplinary field. In the past, it focused mainly on internal integration (Monczka et al., 2009) whereas nowadays, it has focused more on suppliers and customers to reach optimal levels of performance. SCM has been defined as the management of an organization's network concerned with the provision of products and services required by the customer. Therefore, SCM represents the most important change in business management practices in today's business environment (Dumitrascu et al., 2020). Lambert (2008) pointed out that the one reason why there is an increasing interest in SCM is because of organizations depending on effective supply chains, or networks, to successfully compete in the global market. According to the Council of Supply Chain Management Profession (CSCMP) (2021) the supply chain management include: the planning and management of all activities involved in sourcing and procurement, conversion, and all logistics management activities.

\subsection{Benefits of supply chain management}

It is important for organizations to be aware of the concepts and practices of supply chain management and its role in achieving competitiveness and increasing profits (Phan et al., 2020; Karamouz, 2020; Al-Shqairat, et al., 2020; Zulfiqar, et al. 2020; Al Shraah et al., 2021; Childhouse \& Towill, 2003). Also, organizations which intend to be successful appreciate that in today's fast changing and interconnected business environment, associated with mass globalization, they will not survive in isolation but rather as single entity of an integrated supply chain (Hussain et al., 2019; Tan et al., 2002) where there are strong relationships with those within that chain (Abu-Rumman, 2018). Nuthall (2003) recognized four main supply chain objectives for any organization intending to apply SCMPs. They included: operational cost; time and response; quality improvement; customer services; and profitability and margins. Tan (2002) perceived that there are two key benefits of supply chain management: the short term which includes increasing productivity; efficiency; reducing inventory and cycle time, and in the longer term, enhancing customer satisfaction, market share, and profits.

\subsection{Supply chain management and organizational performance}

Professionals and academicians alike agree that supply chain management is a means to create and sustain a competitive advantage and to improve OP for the organization and for the entire supply chain (Li et al., 2006; Mentzer et al., 2001, AlMadi, 2017; Al-Shqairat, et al., 2020; Zulfiqar, et al. 2020). Overall, many studies have shown a clear interest in investigating the impact of SCMPs on business and operational performances (Al-Shqairat et al., 2020; Zulfiqar et al. 2020; Sharma \& Modgil, 2019; Phan et al., 2019; Bozarth et al., 2009; Cai et al., 2009; Lawson et al., 2009). Sharma and Modgil (2019) investigated the impact of TQM and SCMP on organizational performance and their interlinkage between each other. They found that TQM has a direct impact on OP. Moreover, they found that TQM practices directly impacted supply chain components, which in turn, influences overall organizational performance. Phan et al. (2019) studied the impact of supply chain quality management practices (SCQMP) on operational performance in Vietnamese manufacturing companies. They found that implementing SCQMP are more focused on internal quality management practices than upstream and downstream quality management practices. However, their study confirms the significant linkage between SCQMP and OP depending on the correlation and regression analysis. Al-Shboul et al. (2018) showed in their study that quality management, customer focused, and supplier collaboration are considered as the best SCMPs in Gulf manufacturing firms. Surprisingly, their study revealed that lean production cannot yet be qualified to be among the best SCMPs. Li et al. (2006) developed a study to test the relationship between SCMPs, competitive advantage, and OP. They stated that higher levels of SCMPs can lead to enhanced competitive advantage and improve OP. Tan et al., (2002) also examined the relationships between SCMPs, supplier evaluation practices and OP. The SCMPs that have been chosen for his study include: supply chain integration; information sharing; supply chain characteristics; customer service management; geographical proximity; and JIT capability. The study found a positive correlation between geographical proximity, market share and supply chain characteristics. Also, they found that JIT capability had the strongest impact on performance. Salhieh (2011) examined the relationship between SCMPs and organizational financial performance in manufacturing companies. The study results explored the significant correlation between SCMPs and technical efficiency as a measurement of organizational financial performance. Karimi and Rafiee (2014) conducted an empirical study to test a framework identifying the relationship between SCMPs, competitive advantage, and OP. The findings of the study provided empirical evidence to support what has been found in the literature regarding the impact of SCMPs on competitive advantage and OP. Miguel and Brito (2011) investigated the impact of SCM on operational performance in a sample of 103 Brazilian companies. The results of the study revealed that there is a positive impact of SCM on OP. Cheng and Whittmore (2008) conducted a study to investigate the SCM techniques that have been implemented in industries outside healthcare to identify the possibility of applying these techniques in the healthcare industry. The study concluded that implementation of an offsite inventory in which the inventory is gathered, leads to a great deal of savings in hospital supply chains. Zhou and Benton (2007) proposed that effective SCPs and information sharing could enhance the supply chain environment. The outcomes of their study showed that both effective information sharing, and SCPs are a prerequisite to achieve an improvement in supply chain performance. 


\section{Study Importance and Problem Statement}

In a highly competitive and globalized business environment where customers around the world are becoming more demanding; it becomes obvious that only organizations that deliver quality products through building a rigorous relationship with their suppliers will flourish (Adem and Virdi, 2021). There are several reasons why firms in general, and medical firms in specific, need to look at how they manage their supply chain. The main ones are to reduce cost and minimize risk associated with any transaction (Kim and Kim, 2019). Reducing costs while delivering high-quality medical care is a top strategic imperative, including the potential reduction in supply chain costs through better SCMPs. Thus, the current study aimed to investigate the practices of supply chain, to develop a thorough understanding of key principles and practices characterizing the creation of excellent SCMPs within the Jordanian context. In addition, previous studies in supply chain management have primarily sought to explain the nature of the relationship processes rather than their impact on performance, and so this study makes a valuable contribution in addressing this gap. Furthermore, the importance of this study came from the importance of its topic which became an essential enabler of business, in addition to the tangible increase of interest about managing the supply chain at both national and international level. Also, the study's importance came from the fact that there are few studies about supply chain practices in Jordan and the Arab World in general. Therefore, this study is prepared to answer the question of whether there is an impact of supply chain practices on organizational performance. Accordingly, the results of this study can be considered as a base for decision makers at medical firms in Jordan to be more concerned about managing their supply chain to gain competitiveness.

\section{Research Methodology, model, and hypotheses}

For the purpose of this study, five distinctive dimensions are selected to measure supply chain management practices, which been adopted from Li et al. (2006) and supported by some scholars like; Karimi and Rafiee (2014); Salhieh (2011) Chow et al. (2008) and Sengupta et al. (2006). These dimensions include strategic supplier partnership; customer relationship management; level of information sharing; quality of information sharing and postponement. The previous research emphasized that there is a reasonable impact of SCMPs and OPs such as Mentzer et al. (2001), Li et al. (2006), Bozarth et al. (2009), Cai et al. (2009), Lawson et al. (2009), Al-Madi et al. (2013), Al-Madi (2017), Sharma and Modgil (2019), Phan et al. (2019), Al-Shqairat et al. (2020) Zulfiqar et al. (2020). Al-Shboul et al. (2018) and Tan et al. (2002) indicated that the good supply chain is an indicator of quality, financial performance, and competitive advantage. However, most of the studies were conducted in developed countries. Hence, the current study has been conducted to fill the research gap in developing countries, Jordan as an example. As shown in Fig. 1, the conceptual model has been developed by the researchers after an extensive visit of the literature. The model was validated through a two-stages approach of Structural Equation Modeling (SEM). Quantitative approach utilizing a self-administered questionnaire, was employed to arrive at the major findings of the study. The study includes main hypothesis, and five sub-hypotheses as follows:

\section{Hypotheses of the study:}

The main hypotheses of the study were:

$\mathbf{H}_{\mathbf{a}}$ : SCMPs influence on Organizational Performance (OP).

The main hypothesis has been divided into sub-hypotheses:

$\mathbf{H}_{\mathbf{a} 1}$ : Strategic supplier partnership influences on $O P$.

$\mathbf{H}_{\mathbf{a} 2}$ : Customer relationship management influences on $O P$.

$\mathbf{H}_{\mathbf{a} 3}$ : Level of information sharing influences on $O P$.

$\mathbf{H}_{\mathbf{a} 4}$ : Quality of information sharing influences on $O P$.

$\mathbf{H}_{\text {a5: }}$ Postponement influences on OP.

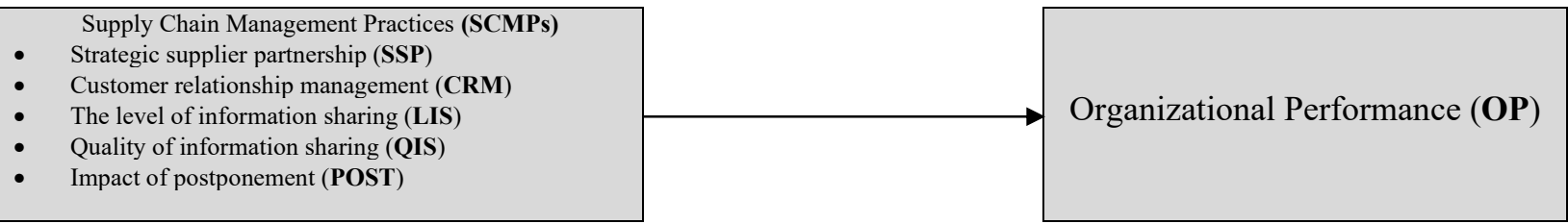

\subsection{Research instrument}

Fig. 1. The research Model (SCMPs on the OP)

This study used a questionnaire survey to investigate the impact of SCMPs on OP. Ghauri et al. (1995) stress that questionnaires are the most popular data collection method in business studies and Collis and Hussey (2003) reported that a positivistic paradigm suggests that closed questions should be used in designing the questionnaire. Thus, the structured 
questions used in the survey were derived following a critical review of the related literature and employed a Five- Point Likert Scale, which was anchored by the end points of "strongly agree" (5) to "strongly disagree" (1). It was noticed that it has been extensively used by the researchers in business studies and was found appropriate to rate all relevant alternatives along the continuum for the respondents to express their opinions and permit good scale discrimination. The questionnaire consisted of (35) items, divided into (29) items that measured the SCMPs; (strategic supplier partnership (SSP), customer relationship management (CRM), level of information sharing (LIS), quality of information sharing (QIS), and postponement (POST)) and (6) items that measure the organizational performance. The SCMPs were adopted from the following studies (Hong et al., 2020; Karamouz et al., 2020; Phan et al., 2019; Adballah \& Al-Ghwayeen, 2019; Duong et al., 2019, Hong et al., 2019; Hong et al., 2018), while the OP dimentions were adopted from (Saho and Vijavargy, 2020, Younes and Sundarakani, 2019; Siddh et al., 2018).

\subsection{Population of sample}

The population of the study consists of all medical devices firms listed in Amman Stock Exchange (ASE) in 2019. There are 150 medical devices firms in Jordan who specialized in: Sterilization; Surgical; Ophthalmology; Anesthesia; Endoscopy; Hospital/ Clinical furniture; Radiology; and Imaging devices. Simple random sampling technique has been utilized to select the appropriate sample. The study population includes all managers in the top management of medical devices firms. This population consisted of 861 managers. 246 questionnaires were distributed online to biomedical top managers including: purchasing managers; marketing managers; quality managers, operations managers; and supply chain managers- employed by these firms -as they are expected to provide reliable data. 207 questionnaires were returned with response rate of (84.1\%). However, 7 questionnaires were dropped from data analysis as they deemed invalid due to missing data, leaving 200 questionnaires to be valid for analysis. This response rate is considered as acceptable according to (Sekaran \& Bougie, 2016; Mugenda \& Mugenda, 2003).

\subsection{Analysis}

Structural Equation Modeling (SEM) was employed to analyze and illustrate the collected data. SEM enabled the conceptual model of this research to be validated. Statistical Package for Social Sciences (SPSS) version 21 and the Structural Equation Modelling (SEM) were employed, with the use of (AMOS:21) have been used to test the hypothesis. The correlation of observed variables and reliability scores (Cronbach's alpha) and descriptive analysis were calculated using SPSS. The result of normality test revealed that the gathered data were normally distributed; therefore, the parametric tests were adopted for this study.

\subsection{Reliability test}

Reliability indicates the consistency of a measure and the probability of obtaining the same results again if the measure were duplicated. An instrument is consistent if the items are highly correlated with each other; therefore, they are likely to measure the same homogenous variable. Hence, according to Sekaran, and Bougie, (2016), reliability is concerned with the stability and consistency with which the instrument measures the concept and helps to assess the goodness of fit of a measure. The Cronbach's Alpha was used to test the stability of the scale, which indicated how well the items measuring a concept hang together as a set. It was computed in terms of the average inter-correlations among the items measuring the concept. The Cronbach's alpha reliability value of SCMPs (the independent variable) is 0.936 , and for OP (the dependent variable) is 0.833 , which is according to Sekaran and Bougie (2016) considered acceptable as the values are greater than (0.6).

\section{Data Analysis and Respondent profile}

Fig. 2 shows that the $(63 \%)$ of the respondents were male, which seems to reasonable as the majority of the workforce in Jordanian context are male.

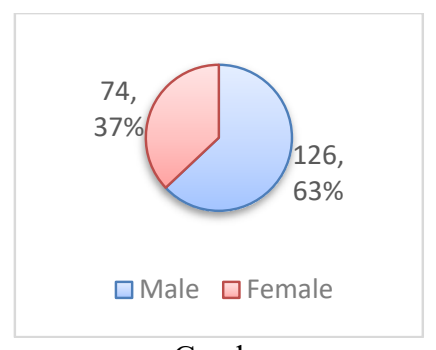

Gender

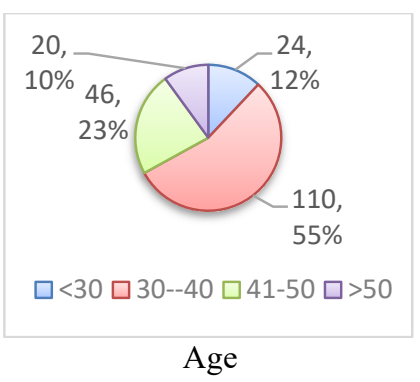

Age 


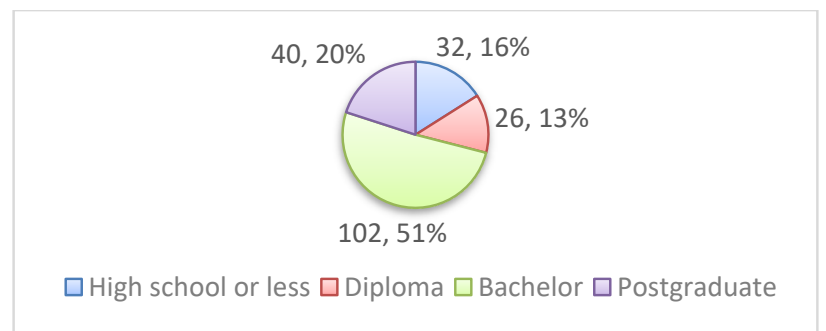

Level of Education

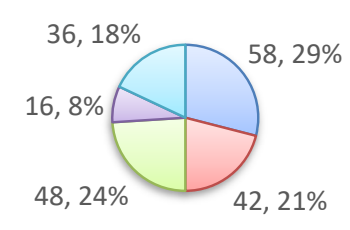

$\square<5 \quad \square 5--10 \quad \square 11--15 \quad \square 15--20 \quad \square>20$

Fig. 2. Personal characteristics of the participants

The greater part of the respondents was within the age group of 30-40 years of age (55\%). This is expected as the people with this age could be promoted to hold a middle-management position through their career path. Also, $51 \%$ of respondents had a bachelor's degree which indicates the respondents were generally well qualified. Many employee respondents' experiences were greater than 5 years which suggests that the study population has good awareness about their work. According to Awang (2015), all items with a factor loading less than 0.60 should be deleted to get a fit model and to test research hypotheses. Fig. 3 presents factor loading for the questionnaire items after confirmatory factor analysis. All the items shown have factor loading higher than 0.60 and therefore achieved the required level.

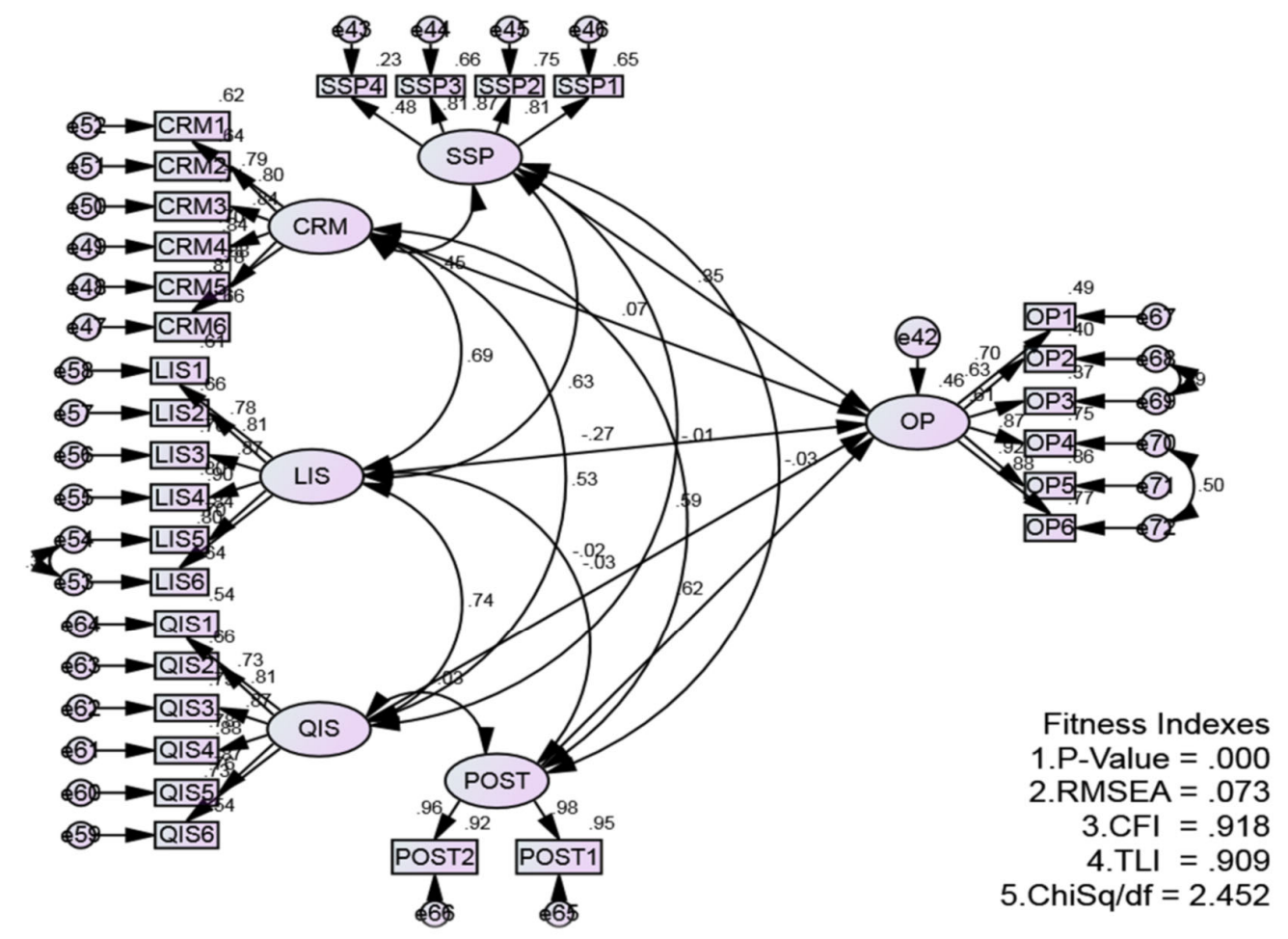

Fig. 3. The Regression Path Coefficient

Fitness indexes appearing in Fig. 3 demonstrate that the measurement model is fit. While p-vale 0.000, RMSEA less than 0.080 (0.073), CFI higher than 0.90 (0.918), and ChiSq/df is less than 3 (2.452). While the unit-dimensionality achieved, the researcher can proceed to test the validity and reliability. Table (2) All Composite Reliability (CR) for model constructs achieve the required level (0.60), and all AVE higher than 0.50 (achieve required level).

Table 1

Discriminant validity and Composite Reliability

\begin{tabular}{cccccccccc}
\hline & CR & AVE & MSV & ASV & QIS & SSP & CRM & LIS & POST \\
\hline QIS & 0.888 & 0.575 & 0.552 & 0.296 & $\mathbf{0 . 7 5 8}$ & & & \\
SSP & 0.810 & 0.584 & 0.393 & 0.236 & 0.593 & $\mathbf{0 7 6 4}$ & \\
CRM & 0.898 & 0.588 & 0.480 & 0.239 & 0.527 & 0.447 & $\mathbf{0 . 7 6 7}$ \\
LIS & 0.891 & 0.608 & 0.552 & 0.356 & 0.743 & 0.627 & 0.693 & $\mathbf{0 . 7 8 0}$ & -0.009 \\
POST & 0.899 & 0.754 & 0.001 & 0.001 & -0.030 & -0.027 & -0.018 & $\mathbf{0 . 8 6 9}$ \\
\hline
\end{tabular}


As mentioned by Awang (2014), discriminant validity is achieved when the value is higher than the values in the same row and column. Table 1 shows that all values in bold (discriminant validity) achieved the required level. The researchers used a regression path coefficient model as show in Table 2 to test the research hypotheses. Table 2 presents the estimates and critical ratio and p-value in the casual effect from each of LS, and PM on ES.

Table 2

Regression Wight

\begin{tabular}{|c|c|c|c|c|c|c|c|}
\hline Hypothesis & Regression weights from & To & Estimate & SE & $\mathbf{C R}$ & $P$ & Result \\
\hline $\mathrm{H}_{\mathrm{a} 1}$ & SSP & OP & .027 & .062 & 1.412 & $* * *$ & Significant \\
\hline $\mathbf{H}_{\mathrm{a} 2}$ & CRM & OP & .0 .101 & 0.115 & 0.883 & 0.037 & Significant \\
\hline $\mathbf{H}_{\mathrm{a} 3}$ & LIS & OP & -0.506 & 0.188 & 0.692 & 0.007 & Significant \\
\hline $\mathbf{H}_{\mathrm{a} 4}$ & QIS & OP & -0.063 & 0.156 & 0.404 & 0.026 & Significant \\
\hline $\mathbf{H}_{\text {a5 }}$ & POST & OP & 0.552 & 0.056 & 0.832 & $* * *$ & Significant \\
\hline
\end{tabular}

Table 2 shows that the direct effect $P$-value (SSP $\rightarrow$ OP) of *** is significant, and direct effect $P$-value $(\mathrm{CRM} \rightarrow \mathrm{OP})$ of 0.037 , direct effect $P$-value (LIS $\rightarrow$ OP) of 0.007 , direct effect $P$-value (QIS $\rightarrow$ OP) of 0.026 , and direct effect $P$-value (POST $\rightarrow$ OP) of ***. According to Awang (2014), if the CR less than $+/-1.96$ the hypothesis will be supported. Table 2 presents all CR as less than 1.96 and the p-value is significant. So, there is an impact of strategic supplier partnership (SSP), customer relationship management (CRM), information sharing (LIS), quality of information sharing (QIS), and postponement (POST) on OP.

\section{Discussion and conclusion}

The main result that can be drawn from this study is summarized by confirming the significant impact of SCMPs on OP in the targeted medical devices firms in Jordan. This is evidenced by the value of the respondent responses mean value (3.9). This result consistent with the findings of several previous studies such as Al Shraah et al. (2021), Hong et al., (2020), Abdullah and Al-Ghwayeen, (2019), Hussain et al., (2019), Hong et al., (2019), Soares et al., (2017), Karimi and Rafiee, (2014), Wagner et al., (2012), Miguel and Brito, (2011), Chow et al., (2008), Koh et al., (2007), Lenny et al., (2007), and Li et al., (2006) which indicated that all supply chain management practices that adopted for this study have a significant impact on organizational performance. However, the study revealed some variances of that impact among the SCMPs. However, the researchers believe that this impact has appears to the surface strongly due to the pandemic of COVID-19. On the other hand, as identified in the analysis, the respondents confirmed that medical devices firms in Jordan have adopted the practices of $\mathrm{SCM}$ as indicated by the overall range of the respondent responses means (3.8). Notwithstanding this overall positive view, firms in Jordan as a developing country should improve their understanding of the importance managing their supply chain to enhance their competitiveness in a global market. This is consistent with the studies of Hussain et al., (2019), Abdullah and Al-Ghwayeen, (2019). Furthermore, the path analysis output revealed that the level of information sharing variable has the most impact on OP amongst other independent variables of SCMPs which is in the vein of the studies conducted by Beber et al., (2019), Mor et al., (2018). So, it could be concluded that strong communication and level of information sharing is a vital issue in managing the supply chain to achieve better business performance. Unfortunately, in developing countries in general and Arab World in particular, a lot of effort required to improve the techniques that will help the firms to increase the level of information sharing with their stakeholders to enhance their competitiveness.

Strategic supplier partnership was also found to have a significant impact on OP. This result is supported by the studies finding of Hong et al., (2020), Abdullah and Al-Ghwayeen, (2019), and Jayalath et al., (2017). The finding also concurs with the findings of a study conducted by Hussain et al., (2019), which emphasized the statistically significant impact of strategic supplier's partnership on organizational performance. Therefore, the firms should build a long and robust relationship with their suppliers to reduce cost and receive products and services of a high quality which leads to enhanced performance of the organization. Also, the findings of the study showed that customer relationship management has a significant impact on OP. Thus, the firms need to tighten their relationship with their customers through taking their needs and wants into consideration with each decision they make. Therefore, successful organizations should do their best to deliver a high value products and services to fully satisfy their customers to gain their loyalty. As a result, medical devices firms in Jordan must be a customerfocused oriented and should encourage their employees to deal with its customer properly. This could be achieved through providing the employees with a proper training on interpersonal skills. Finally, the results revealed that postponement as one of the supply chain management dimensions had the lowest impact on OP. This result seems to be reasonable as the medical devices firms in Jordan are classified to be an SMEs and they could cover the demand of the market. Also, there is a believe by the managers of those firms that any postponement will be resulted in a loss of an opportunities. This result is supported by the studies of some researchers such as, Abu-Rumman, (2018) and Al-Madi, (2017).

As a conclusion, this study was designed primarily to assess the level of SCMPs implementation in the medical devices' firms in Jordan. Also, its designed to examine the impact of SCMPs on OP empirically. The study found a good level of SCMPs implementation (mean $=3.8$ ) but suggested that more can be done in the sense of achieving higher levels of OP than the existing ones. Moreover, the study's findings were consistent with the findings of other studies which also found an impact of SCMPs on OP. 
Regarding financial performance, the results of the study are consistent with Salhieh, (2011) and Wagner et al. (2012) who found that SCMPs have a positive impact on financial performance. In term of operational performance, the results of the study are also consistent with previous research whose findings identified the positive impact of supply chain management on OP. (Bozarth et al., 2009; Cai et al., 2009; Lawson et al., 2009; Lenny et al., 2007; Miguel and Brito, 2011). Overall, the study supports the argument that adopting and implementing the SCMPs, at organizational level, are a prerequisite for successful OP.

\subsection{Managerial Implications}

The findings of the study support the conceptual model and provide a number of managerial implications. First, it offers a practical approach for decision-makers among the Jordanian medical devices firms to evaluate their SCMPs. Second, the study emphasized the effectiveness of SCMPs in increasing the performance of the organizations, hence, decision-makers should adopt SCMPs. Furthermore, managers should realize that competition is between supply chains rather than among organization nowadays. Accordingly, it is becoming imperative to adopt the SCMPs to survive and prosper in the highly fierce competition business environment.

\subsection{Limitations and future research}

The study was not without any limitation, though the impact of the limitation does not compromise the validity of the study outcomes. The scope was limited to medical devices firms in Jordan, which may limit its generalization to other sectors. Therefore, more future studies are suggested to other sectors (manufacturing and service) to test the generalizability of this study findings. The future research is also proposed to apply multiple approaches (quantitative and qualitative) to exclude any potential common method bias and advance the ability of the findings to be generalized. Also, comparative studies could reveal any differences in SCMPs implementation within a different environmental context. Finally, yet important, the researchers would suggest the consideration of some demographic variables such as, firms' age, size, and experience while addressing the impact of SCMPs on OP.

\section{References}

Abdallah, A. B., \& Al-Ghwayeen, W. S. (2019). Green supply chain management and business performance: The mediating roles of environmental and operational performances. Business Process Management Journal, 26(2), 489-512.

Al Shraah, A., Abu-Rumman, A., Al Madi, F., Alhammad, F.A.F. and AlJboor, A.A. (2021). The impact of quality management practices on knowledge management processes: a study of a social security corporation in Jordan. The TQM Journal, Vol. ahead-of-print No. ahead-of-print. https://doi.org/10.1108/TQM-08-2020-0183

Abu-Rumman, A. (2018). TQM and Competitive Advantage: Experiences within the Engineering, Electronics, and IT Industrial Sectors in Amman. In Excellence in Services $21^{\text {st }}$ International Conference, 0-12.

Abu-Rumman, A., Mhasnah, A. \& Al-Zyout, T. (2021). Direct and indirect effects of TQM on the patients' satisfaction and loyalty in the Jordanian health care sector. Management Science Letters, 11(2), 493-502.

Al-Ali, A.H. \& Abu-Rumman, A. (2019). The role of total quality management in the face of challenges: A study in LafargeJordan. Academy of Strategic Management Journal, 18(1), 1-16.

Al-Madi, F., Al-Shra'ah, A. \& Abu Rumman, M. (2013), Knowledge management and strategic decision making in the Jordanian public sector. Journal of Economic \& Engineering, 4(1), 43-55.

Al-Madi, F. (2017). The Impact of Supply Chain Management Practices on Supply Chain Performance in the Jordanian Industrial Sector. European Journal of Business \& Management, 9(15), 150-165.

Al-Shboul, M.A, Garz-Reyes, J.A. \& Kumar, V. (2018). Best supply chain management practices and high-performance firms: The case of Gulf manufacturing firms. International Journal of Productivity \& Performance Management, 67(9), 1482-1509.

Al-Shqairat, Z. I., AL Shraah, A. E. M., \& Abu-Rumman, A. (2020). The role of critical success factors of knowledge stations in the development of local communities in Jordan: A managerial perspective. Journal of management Information \& Decision Sciences, 23(5), 510-526.

Beamon, B. M., (1998). Supply chain design and analysis: models and methods. International Journal of Production Economics, 55(3), 281-94.

Beber, C. L., Carpio, A. F. R., Almadani, M. I., \& Theuvsen, L. (2019). Dairy supply chain in Southern Brazil: barriers to competitiveness. International Food \& Agribusiness Management Review, 22(5), 651-673.

Bozarth, C. C., Warsing, D. P., \& Flynn, B. B. (2009). The impact of supply chain complexity on manufacturing plant performance. Journal of Operations Management, 27(1), 78-93.

Cai, J., Lui, X. D., \& Xiao, Z. H., (2009). Improving supply chain performance management: A systematic approach to analyzing iterative KPI accomplishment. Decision Support Systems, 46(2), 512-521.

Childhouse, P., \& Towill, D. R., (2003). Simplified Material Flow Holds the Key to Supply Chain Integration. The International Journal of Management Science, 31(1), 17-27.

Chow, W. S., Madu, C. N., Kuei, C. H., Lu, M. H., Lin, C., \& Tseng, H., (2008). Supply Chain Management in the US and Taiwan; An Empirical Study. The International Journal of Management Science, 36(2), 665-679. 
Choy, K.L., Lee, W. B., \& Lo, V., (2002). Development of a Case Based Intelligent Customer-Supplier Relationship Management System. Expert System with Applications, 23(3), 281-297.

Collis, J., \& Hussey, R. (2003). Business Research: A practical guide for undergraduate and postgraduate students, Palgrave Macmillan, UK. $2^{\text {nd }}$ ed.

Council of Supply Chain Management Professionals (CSCMP). (2013). Supply Chain Management: Terms and Glossary, Illinois: CSCMP.

Dumitrascu, O., Dumitrascu, M. \& Dobrotă, D. (2020). Performance evaluation for a sustainable supply chain management system in the automotive industry using artificial intelligence. Processes, 8(11), 1384-1394.

Duong, B. A. T., Truong, H. Q., Sameiro, M., Sampaio, P., Fernandes, A. C., Vilhena, E., \& Yadohisa, H. (2019). Supply chain management and organizational performance: the resonant influence. International Journal of Quality \& Reliability Management, 36(7), 1053-1077.

Garcia, M. Ú., (2005). Training and business performance; the Spanish case. International Journal of Human Resource Development, 16(9), 1691-1710.

Ghauri, P. Gronhaug, K. \& Kristianslund, I. (1995). Research Methods in Business Studies: A Practical Guide. Prentic Hall.

Hong, J., Liao, Y., Zhang, Y., \& Yu, Z. (2019). The effect of supply chain quality management practices and capabilities on operational and innovation performance: Evidence from Chinese manufacturers. International Journal of Production Economics, 212, 227-235.

Hong, J., Zhou, Z., Li, X., \& Lau, K. H. (2020). Supply chain quality management and firm performance in China's food industry - the moderating role of social co-regulation. International Journal of Logistics Management, 31(1), 99-122.

Hsu, C. C., Tan, K. C., Kannan, V. R., \& Leong, K. G., (2009). Supply chain management practices as a mediator of the relationship between operations capability and firm performance. International Journal of Production Research, 47, 835855.

Hussain, M., Khan, M., Ajmal, M., \& Khan, B. A. (2019). Supply chain quality management and organizational performance. Benchmarking: An International Journal, 27(1), 232-249.

Jayalath, U., Samarasinghe, G. D., Kuruppua, G. N., Prasanna, R., \& Perera, H. S. C. (2017). Quality management and supply chain management practices towards operational performance: A study of the Rubber manufacturing industry of Sri Lanka. Colombo Business Journal, 8(2), 19-41.

Johnson, M. E., \& Davis, T. (1998). Improving supply chain performance by using order fulfillment metrics. National Productivity Review, 17(3), 3-16.

Karamouz, S.S., Ahmadi Kahnali, R. and Ghafournia, M. (2020). Supply chain quality management performance measurement: systematic review. International Journal of Quality \& Reliability Management, 38(2), 484-504.

Karimi, E., \& Rafiee, M., (2014). Analyzing the impact of supply chain management practices on organizational performance through competitive priorities (Case study: Iran Pumps Company). International Journal of Academic Research in Accounting, Finance, and Management Sciences, 4(1), 1-15.

Kim, C. \& Kim, H.J. (2019). A study on healthcare supply chain management efficiency: Using bootstrap data envelopment analysis. Health Care Management Science, 22(3), 534-548.

Koh, S. C. L., Demirbag, M., Bayraktar, E., \& Zaim, S. (2007). The impact of supply chain management practices on performance of SMEs. Industrial Management \& Data System, 107(1), 103-124.

Lambert, D. (2008). An Executive Summary of Supply Chain Management: Process, Partnerships, and Performance. Jacksonville: The Hartley Press, Inc.

Lawson, B., Cousing, P. D., \& Handfield, R. B. (2009). Strategic purchasing, supply management practices and buyer performance improvement: an empirical study of UK manufacturing organizations. International Journal of Production Research, 47(10), 2649-2667.

Lenny. K., Mehmet. D., Erkan, B., Tatoglu, E., \& Zaim, S. (2007). The impact of supply chain management practices on performance of SMEs. Industrial Management \& Data Analyses, 107(1), 103-124.

Li, S., Nathan, B. R., Nathan, T. S. R., \& Rao, S. S. (2006). The impact of SCM practices on competitive advantage and organizational performance. The International Journal of Management Science, 34, 107-124.

Mentzer, J. T., DeWitt, W., Keebler, J. S., Min, S., Nix, N. W., Smith, C. D., \& Zacharia, Z. G. (2001). Defining supply chain management. Journals of Business Logistics, 22(2), 23-36.

Miguel, P. L. D. S., \& Brito, L. A. L. (2011). Supply chain management measurement and its influence on operational performance. Journal of Operations \& Supply Chain Management, 4(2), 56-70.

Monczka, R. M., Handfield, R. B., Giunipero, L. C., \& Patterson, J. L., (2009). Purchasing and Supply Chain Management. 4th ed., United States of America: South-Western Cengage Learning.

Mor, R. S., Singh, S., \& Bhardwaj, A. (2017). Exploring the causes of low productivity in dairy supply chain using AHP. Jurnal Teknik Industri, 19(2), 83-92.

Mor, R. S., Bhardwaj, A., \& Singh, S. (2018). A structured-literature-review of the supply chain practices in dairy industry. Journal of Operations \& Supply Chain Management, 11(1), 14-25.

Nuthall, L. (2003). Supply chain performance measures and systems. Gower handbook of supply chain management. Burlington, VT: Gower Publishing, 248-66.

Phan, A.C., Nguyen, H.A., Trieu, P.D., Nguyen, H.T. \& Mastsui, Y. (2019). Impact of supply chain quality management practices on operational performance: empirical evidence from manufacturing companies in Vietnam. Supply Chain Management: An International Journal, 24(6), 855-871. 
Salhieh, L. (2011). An Exploratory Study of the Relationship between supply chain management practices and technical efficiency of Jordanian manufacturing companies. International Journals of Business \& Management, 6(12), 1-9.

Sahoo, S., \& Vijayvargy, L. (2020). Green supply chain management practices and its impact on organizational performance: evidence from Indian manufacturers. Journal of Manufacturing Technology Management, Vol. ahead-of-print No. aheadof-print.

Sekaran, U \& Bougie, R. (2016). Research Methods for Business: A skill Building Approach. 7th ed., John Wiley \& Sons Inc, New York, NY.

Sengupta, K., Heiser, D. R., \& Cook, L. S. (2006). Manufacturing and service supply chain performance: a comparative analysis. Journal of Supply Chain Management, 42(4), 4-15.

Sharma, S. \& Modgil, S. (2019). TQM, SCM and operational performance: an empirical study of Indian pharmaceutical industry. Business Process Management Journal, 26(1), 331-370.

Siddh, M. M., Soni, G., Jain, R., \& Sharma, M. K. (2018). Structural model of perishable food supply chain quality (PFSCQ) to improve sustainable organizational performance. Benchmarking: An International Journal, 25(7), 2272-2317.

Soares, A., Soltani, E., \& Liao, Y. Y. (2017). The influence of supply chain quality management practices on quality performance: an empirical investigation. Supply Chain Management: An International Journal, 22(2), 122-144.

Tan, K.-C., Kannan, V. R., Handfield, R. B., \& Ghosh, S., (1999). Supply chain management: an empirical study of its impact on performance. International Journal of Operations \& Production Management, 19(10), 1034-1052.

Tan, K. C., Lyman, S. B., \& Wisner, J. D., (2002). Supply chain management: a strategic perspective. International Journal of Operations \& Production Management, 22(6), 614-631.

Tharenou, P., Saks, A. M., \& Moore, C., (2007). A review and critique of research on training and organizational-level outcomes. Human Resource Management Review, 17, 251-273.

Wagner, S.M., Grosse-Ruykena, P.T., \& Erhunb, F., (2012). The link between supply chain fit and financial performance of the firm. Journal of Operations Management, 30(4), 340-353.

Xiao, C., Petkova, B., Molleman, E. \& van der Vaart, T. (2019). Technology uncertainty in supply chains and supplier involvement: the role of resource dependence. Supply Chain Management: An International Journal, 24(6), 697-709.

Yasmin, S., Gunasekruan, A., \& Mavondo, F. T., (1999). Relationship between generic strategy, competitive advantage, and firm performance: an empirical analysis. Technovation, 19(8), 507-518.

Younis, H., \& Sundarakani, B. (2019). The impact of firm size, firm age, and environmental management certification on the relationship between green supply chain practices and corporate performance. Benchmarking: An International Journal, 27(1), 319-346.

Zhou H. \& Benton W.C. J., (2007). Supply chain practice and information sharing. Journal of Operations Management, 25, $1348-1365$.

Zulfiqar, U., Mohy-Ul-Din, S., Abu-rumman, A., Al-Shra'ah, A.E., \& Ahmed, I. (2020). Insurance-Growth Nexus: Aggregation and Disaggregation. Journal of Asian Finance, Economics \& Business, 7, 665-675. 
(C) 2021 by the authors; licensee Growing Science, Canada. This is an open access article distributed under the terms and conditions of the Creative Commons Attribution (CCBY) license (http://creativecommons.org/licenses/by/4.0/). 